\title{
Iron oxide deposits associated with the ectosymbiotic bacteria in the hydrothermal vent shrimp Rimicaris exoculata
}

\author{
L. Corbari ${ }^{1}$, M.-A. Cambon-Bonavita ${ }^{2}$, G. J. Long ${ }^{3}$, F. Grandjean ${ }^{4}$, M. Zbinden ${ }^{5}$, F. Gaill ${ }^{5}$, and P. Compère ${ }^{1}$ \\ ${ }^{1}$ Université de Liège, Laboratoire de Morphologie fonctionnelle et Evolutive, Unité de Morphologie ultrastructurale et Cellule \\ d'Appui Technologique en Microscopie (Cat $\mu$ ), allée de la chimie, 3, 4000 Liège, Belgium \\ ${ }^{2}$ Laboratoire de Microbiologie et Biotechnologie des Extrêmophiles, Ifremer, centre de Brest, BP 70, 29280 Plouzané, France \\ ${ }^{3}$ Department of Chemistry, Missouri University of Science and Technology, University of Missouri-Rolla, Rolla, Missouri \\ 65409-0010, USA \\ ${ }^{4}$ Department of Physics, B5, University of Liège, 4000 Sart-Tilman, Belgium \\ ${ }^{5}$ UMR CNRS 7138 "Systématique, Adaptation et Evolution", Université Pierre et Marie Curie, 7 Quai St Bernard, Bâtiment \\ A, 75252 Paris Cedex 05, France
}

Received: 12 February 2008 - Published in Biogeosciences Discuss.: 24 April 2008

Revised: 1 August 2008 - Accepted: 14 August 2008 - Published: 10 September 2008

\begin{abstract}
The Rimicaris exoculata shrimp is considered as a primary consumer that dominates the fauna of most Mid-Atlantic Ridge (MAR) hydrothermal ecosystems. These shrimps harbour in their gill chambers an important ectosymbiotic community of chemoautotrophic bacteria associated with iron oxide deposits. The structure and elemental composition of the mineral concretions associated with these bacteria have been investigated by using LM, ESEM, TEM STEM and EDX microanalyses. The nature of the iron oxides in shrimps obtained from the Rainbow vent field has also been determined by Mössbauer spectroscopy. This multidisciplinary approach has revealed that the three layers of mineral crust in the Rimicaris exoculata shrimps consist of large concretions formed by aggregated nanoparticles of two-line ferrihydrite and include other minor elements as $\mathrm{Si}$, $\mathrm{Ca}, \mathrm{Mg}, \mathrm{S}$ and $\mathrm{P}$, probably present as silicates cations, sulphates or phosphates respectively that may contribute to stabilise the ferrihydrite form of iron oxides. TEM-observations on the bacteria have revealed their close interactions with these minerals. Abiotic and biotic precipitation could occur within the gill chamber of Rimicaris exoculata, suggesting the biologically-mediated formation of the iron oxide deposits. The difference of the bacterial density in the threemineral crust layers could be correlated to the importance of the iron oxide concretions and suggest that the first mineral particles precipitates on the lower layer which could be considered as the most likely location of iron-oxidizing bacteria.
\end{abstract}

Correspondence to: L. Corbari (lcorbari@ulg.ac.be)

\section{Introduction}

Rimicaris exoculata (Williams and Rona, 1986) is one of the most dominant species found at the Mid-Atlantic Ridge (MAR) hydrothermal vents. This endemic shrimp swarms on the chimney walls, exhibiting a patch-like distribution of up to several thousand per square meter (Segonzac et al., 1993). In extreme deep-sea environments, such high population density levels require some specific adaptations. Many hydrothermal organisms derive their nutrition from chemoautotrophic bacteria through symbioses relying most often on sulphide or methane as an energy source (Cavanaugh, 2006). $R$. exoculata possess an original ectosymbiotic bacterial community, housed in its expanded gill chambers and mouth parts (Van Dover et al., 1988; Casanova et al., 1993; Zbinden et al., 2004; Corbari et al., 2008). Even though numerous authors have suggested that, if really ectosymbiotic, the bacteria could be a direct or indirect food source for the shrimp (Segonzac et al., 1993; Rieley et al., 1999; Gebruk et al., 2000; Zbinden et al., 2004, 2008). Still undetermined, however, is the origin of the nutritional carbon of $R$. exoculata and the role of the bacterial ectosymbiosis play as a trophic resource (Pond et al., 1997; Polz et al., 1998; Zbinden and Cambon-Bonavita, 2003). The bacterial community housed in the gill chamber of $R$. exoculata has been identified as chemoautotrophic bacteria (Wirsen et al., 1993) and phylogenetic analysis revealed that the bacteria could correspond to a single epsilon-proteobacteria phylotype (Polz and Cavanaugh, 1995). Some authors have also hypothesized that the bacteria could acquire their energy from sulphide oxidation (Gebruk et al., 1993; Polz and

Published by Copernicus Publications on behalf of the European Geosciences Union. 
Cavanaugh, 1995), but this hypothesis has never been confirmed by any culture experiment. Recently, Zbinden et al. (2008) demonstrated that the bacterial community in the shrimp gill chamber is composed of more than one phylotype and revealed from molecular analysis that three metabolic bacterial types (iron, sulfide and methane oxidation) may cooccur within the symbiotic community associated with Rimicaris exoculata.

In the absence of cultivated bacteria, studies have focussed on the description of both the bacteria and the mineral deposits in R. exoculata. Zbinden et al. (2004) described three bacterial morphotypes, individual rods with an approximate size of $0.5 \times 1.5 \mu \mathrm{m}$, and two types of multicellular filaments, i.e. thick filaments with 2 to $3 \mu \mathrm{m}$ diameters and thin filaments with 0.5 to $1 \mu \mathrm{m}$ diameters, found within the entire gill chamber. They mapped the location of these bacteria and divided their associated minerals into three functional compartments, that which were considered to represent distinct microenvironments. One of these compartments, the upper prebranchial chamber, houses the highest density of both bacteria and minerals. Recently, Corbari et al. (2008) focussed on this compartment and delineated the shrimp-bacteria-mineral association throughout the shrimp moult cycle. This study performed on about 300 specimens from two vent sites, TAG and Rainbow, indicated that the bacterial community restarts after each exuviation and gradually colonises the gill chamber in five moult stage-correlated steps. Moreover, the presence of red-brown mineral deposits in the gill chamber, including the mouth parts and branchiostegites, of the R. exoculata has already been described (Gloter et al., 2004; Zbinden et al., 2004). These deposits have been identified as hydrous iron oxide in the form of ferrihydrite (Gloter et al., 2004). The extent and density of iron oxide deposits within the gill chamber are both responsible for the external colour of the shrimp, a colour that may be macroscopically observed by transparency through the branchiostegites (Zbinden et al., 2004). The shrimp external colour ranges from white, indicative of no mineral deposits, to dark-red, indicative of a heavily mineralised crust; the colour appears to be highly correlated with the moult stages (Corbari et al., 2008). The fullyformed mineral crust is roughly organised in three step-levels that illustrate the time-related formation and growth of the mineral particles (Corbari et al., 2008). The shrimp-bacteria ectosymbiosis is characterised by the presence of iron oxide deposits suggesting that iron oxidation may represent the major energy-pathway for the bacterial community, especially in shrimps found at the Rainbow site (Gloter et al., 2004; Zbinden et al., 2004, 2008; Schmidt et al., 2008). Moreover, the simultaneous occurrence of the bacteria and the iron oxide deposits in the gill chamber of $R$. exoculata may be interpreted as biologically-mediated or biogenic (Zbinden et al., 2004; Gloter et al., 2004, Anderson et al., 2008).

The definition of "biogenic iron oxides" (Fortin and Châtellier, 2003) refers to iron oxides formed in the presence of bacteria and includes iron oxides formed as a di- rect result of microbial activities (i.e. from enzymatic reactions) or of passive mechanisms whereby bacterial exudates trigger the formation and precipitation of iron oxides minerals. Several studies have documented the formation and occurrence of iron oxides formed as a result of biotic pathways in natural environments (Fortin et al., 1998; Fortin and Châtellier, 2003; Fortin and Langley, 2005; Banfield et al., 2000; Kennedy et al., 2003, 2004). In this context, the bacteria-hydrous ferric oxide interactions have also been investigated to determine the direct and/or indirect bacterial influence on the hydrous ferric oxide formation (see reviews in Fortin and Langley, 2005; Klapper and Straub, 2005). Some authors (Mavrocordatos and Fortin, 2002; Rancourt et al., 2005) have indicated that bacteria, either iron-metabolizing or non-metabolizing, could influence the mineral deposition. They found evidence of the biogenic origin of the hydrous ferric oxide, identified the presence of poorly crystallized iron oxides, and determined the typical Fe/O ratios and particle size ranges. Natural biogenic iron oxides generally contain impurities, such as adsorbed or structural $\mathrm{Si}$, and phosphate, sulphate, and manganese and aluminium ions, impurities that may influence the spatial organization and the morphology of the mineral particles (Fortin and Châtellier, 2003, Châtellier et al., 2004). The properties of the iron oxide deposits and the influence of any impurities on these properties have been studied in samples from natural environments (Fortin and Langley, 2005) but have never been investigated in the case of a bacterial ectosymbiosis.

Because the iron oxide deposition could be actively or passively promoted by $R$. exoculata ectosymbiotic bacteria, the main goal of this study is to investigate in detail the structure and the composition of the bacteria-associated mineral particles by using various imaging techniques, such as back-scattered electron imaging, transmission electron microscopy, energy dispersive EDX microanalysis, and Mössbauer spectroscopy. These investigations have been performed on the fully formed mineral crust of premoult shrimps, a crust that is divided into three layers related with the successive steps of formation and growth of the mineral particles.

\section{Materials and methods}

\subsection{Shrimp selection and samples treatment}

Specimens of Rimicaris exoculata were collected during the French cruise "EXOMAR" (August 2005) at the MAR hydrothermal vent site Rainbow $\left(36^{\circ} 14^{\prime} \mathrm{N}, 33^{\circ} 54^{\prime} \mathrm{W}, 2300 \mathrm{~m}\right.$ depth) by using the suction sampler of the ROV "Victor 6000 " operating from the RV "Atalante." Immediately after retrieval, entire living specimens were either frozen at $-80^{\circ} \mathrm{C}$ or dissected into body parts, branchiostegite and tail, and fixed in a $2.5 \%$ glutaraldehyde in seawater $7 / 10$ at $\mathrm{pH} 7.2$ medium. 
Observations and analyses were performed on preecdysial specimens, in moult stages $\mathrm{D}_{1}$ "” and $\mathrm{D}_{2}$, in agreement with the moult-staging method of Drach and Tchernigovteff (1967), based on the development of setae matrices along the uropods borders. The six frozen and four glutaraldehydefixed specimens all exhibited an important red-mineral crust on the inner side of the gill chamber (Fig. 1a and b) in agreement with the colour categorisation by Corbari et al. (2008). All the observations were performed on the dorsal median zone of the branchiostegite of $R$. exoculata (Fig. 1a) because it exhibits a regular bacterial and mineral cover that lines the antero-dorsal compartment of the gill chamber (Zbinden et al., 2004). The complete branchiostegite and some portions were photographed with an Olympus SZ40 stereo microscope.

In order to determine the structure and elemental composition of the bacteria-associated minerals, samples were prepared for study by transmission and scanning electron microscopy, EDX microanalysis, and Mössbauer spectroscopy. During theses preparations, contact between air and the samples was avoided to prevent alteration in the oxidation and/or hydration states of the iron oxide minerals. To avoid this aircontact, frozen specimens were used for compositional analyses and compared with glutaraldehyde-fixed specimens. For analytical electron microscopy measurements, the samples, dissected from frozen specimens, were directly dehydrated in absolute ethanol and embedded in epoxy resin (Epofix, Struers) through propylene oxide. Glutaraldehyde-fixed samples, conserved in seawater with $\mathrm{NaN}_{3}$, were quickly rinsed in distilled water and dehydrated through an ethanolpropylene oxide series of rinses before embedding in the EpoFix resin (Struers).

\subsection{Scanning Electron Microscopy (SEM) and Energy- Dispersive X-ray (EDX) microanalysis}

Polished thin slices of 20 to $50 \mu \mathrm{m}$ thickness were obtained for the branchiostegites of two glutaraldehyde-fixed and two frozen specimens. The specimens were cut as vertical crosssections through the mineral crust, i.e. perpendicular to the branchiostegite cuticle. They were polished by abrasion on diamond disks and finally mirror polished with a nonaqueous $1 \mu \mathrm{m}$ diamond suspension (ESCIL, PS-1MIC). The polished-thin slices were surrounded with a conductive silver paint to make contact on the surface, carbon-coated in a Balzers BAF-400 rotary evaporator, and then maintained in desiccators to prevent air-contact before analysis. Structural mineral observations and elemental energy-dispersive $\mathrm{X}$-ray microanalysis were rapidly performed within two days of preparation in an environmental scanning electron microscope (FEI XL30 ESEM-FEG), operating at 15 to $20 \mathrm{kV}$ and a working distance of $10 \mathrm{~mm}$. A total of 15 polishedthin slices were imaged by back-scattered electrons (BSE) and analysed for the elemental composition of the minerals present.

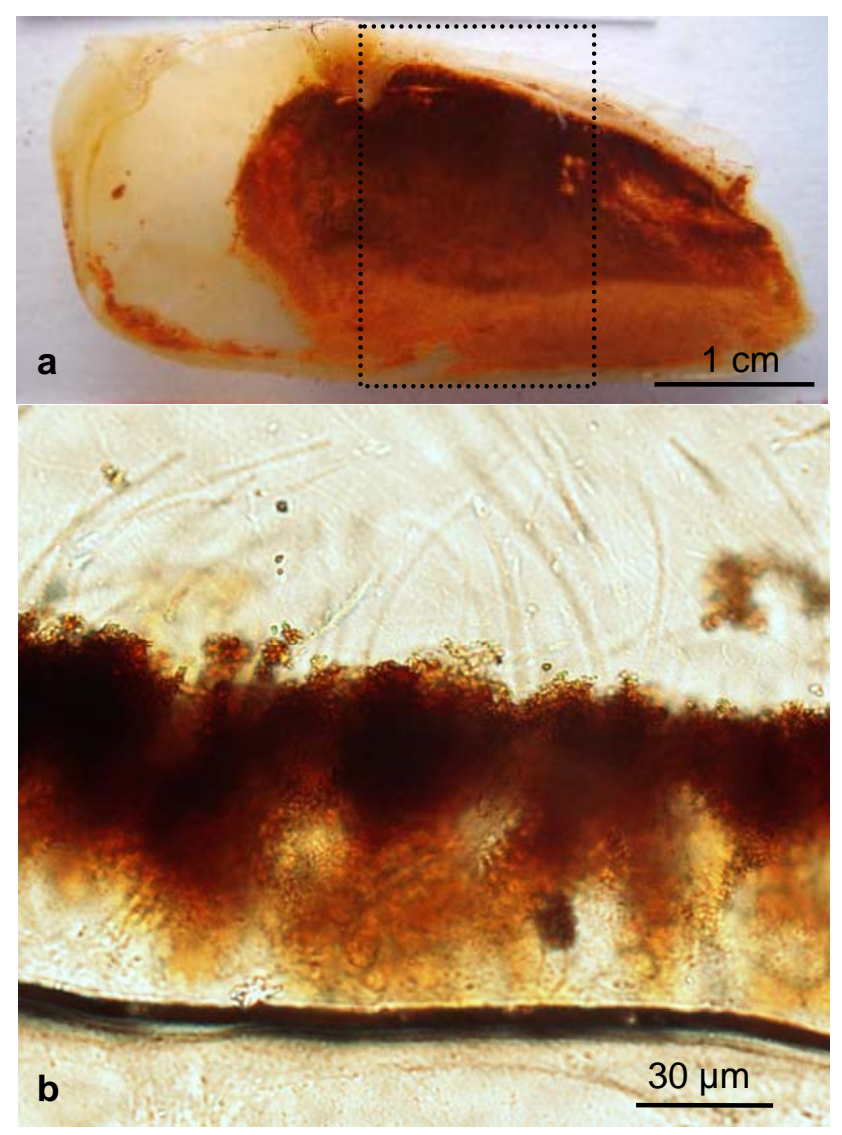

Fig. 1. Rimicaris exoculata. (a) Inner side of the branchiostegite (left side) of premoult specimen in moult stage D1"' exhibiting a dense and uniform coating of mineral deposits. The dashed lines delimit the observed area, the median zone. (b) Polished thin cross section slices of the mineral crust observed under a light microscope and exhibiting three different layers of mineral density. Note that the bacterial filaments are distinguishable on the upper level of the picture.

Elemental analyses have been carried out on the surface of $2 \mu \mathrm{m}$ size mineral concretions. EDX microanalyses with an acquisition time of $60 \mathrm{~s}$ have been obtained for both the glutaraldehyde-fixed and the frozen samples in order to determine whether any mineral transformation took place through chemical reactions during sample preparation. The elemental quantitative analysis used an automatic background subtraction and a ZAF correction matrix has been used to calculate the elemental composition in weight percents and atomic percents. For quantitative analysis of the mineral concretions, the contributions of the $\mathrm{C}$-coating and the embedding resin containing $\mathrm{C}, \mathrm{O}$ and trace of $\mathrm{Cl}$ were subtracted from the quantitative data of each spectrum. The contribution of C-coating was evaluated to $25 \mathrm{At} \%$ of $\mathrm{C}$ from a pure mineral sample (hydroapatite) $\mathrm{C}$-coated in the same conditions. The remaining $\mathrm{C}$ was attributed to the resin and 
an amount of O (At \%) was subtracted in the same proportion, deduced from reference spectra of pure resin $(\mathrm{C} / \mathrm{O}$ ratio $8: 1)$.

\subsection{Transmission Electron Microscopy (TEM)}

Four glutaraldehyde-fixed specimens were post-fixed in osmium $1 \%$, dehydrated in an ethanol-propylene oxide series and then embedded in epoxy resin (SPI-PON 812). Ultrathin sections were obtained with a Reichert-Jung Ultramicrotome (Ultracut E) by using a diamond knife; uranium acetate and lead citrate were used as contrast agents. The specimens were studied with a Jeol (JEM 100-SX) transmission electron microscope operating at $80 \mathrm{kV}$. In order to provide a threedimensional view of the mineral crust organisation, vertical cross-sections were cut perpendicular to the branchiostegite cuticle and the mineral surface and horizontal sections were cut at the three levels of mineral crust as the previously defined.

\subsection{Scanning Transmission Electron Microscopy (STEM) and Energy-Dispersive X-ray (EDX) microanalysis}

Ultrathin sections of samples from two frozen shrimps were cut as previously described, placed on a formvar-coated titanium grid and carbon-coated in a Balzers BAF-400 rotary evaporator. They were then imaged without any additional contrast in a FEI Tecnai G2 Twin scanning-transmission electron microscope operating at $200 \mathrm{kV}$.

In order to determine the elemental composition of the strata observed in the mineral concretions, scanning transmission electron imaging has been carried out in a both direct bright-field and a high-angle annular dark-field (HAADF) imaging modes. The energy-dispersive EDX nanoanalyses were performed with a nanoprobe spot size of $1 \mathrm{~nm}$ in diameter. Profile spectra have been determined on 1 to $1.5 \mu \mathrm{m}$ length of ten various mineral concretions.

\subsection{Mössbauer spectroscopy}

The Mössbauer spectra have been obtained on samples from frozen shrimps. Two different types of Mössbauer spectral absorbers have been used. The first contained boron nitride mixed with $14 \mathrm{mg} / \mathrm{cm}^{2}$ of lyophilized powder of crust minerals obtained by scrapings from three shrimps. The second consisted in the superimposed branchiostegites of one shrimp. The spectra were measured between 4.2 and $295 \mathrm{~K}$ on a constant-acceleration spectrometer that utilised a room temperature rhodium matrix cobalt-57 source and was calibrated at $295 \mathrm{~K}$ with $\alpha$-iron powder. The estimated relative errors are $\pm 0.005 \mathrm{~mm} / \mathrm{s}$ for the isomer shifts, $\pm 0.01 \mathrm{~mm} / \mathrm{s}$ for the quadrupole splittings and line widths, and ca. $\pm 0.5 \mathrm{~T}$ for the hyperfine field. The absolute errors are estimated to be approximately twice as large.

\subsection{Statistical analysis}

The mineralogical compositions and quantifications are reported as mean values \pm standard deviation. Comparisons of the mineral composition between glutaraldehyde-fixed and frozen samples have been evaluated by using a MannWhitney U-test, a two-tailed Student's $t$-test, a Fisher test, and/or analysis of the variance. $P<0.05$ was taken as the fiducial limit for statistical significance.

\section{Results}

\subsection{Mineral crust ultrastructure}

The formation of a thick mineral crust overlying the bacterial community in the medium zone of the branchiostegites (Fig. 1a) of dark-red shrimps has been previously described (Corbari et al., 2008). Three levels in the crust were arbitrarily defined according to the aggregate density that gradually increases from the cuticle towards the top surface of the crust. All analysed specimens of Rimicaris exoculata exhibit on the inner side of their branchiostegites, a dense, compact, mineral coating with a thickness of up to $100 \mu \mathrm{m}$, a mineral coating that corresponds to the mineral crust (Fig. 1b). BSE images of the vertical sections obtained in polished thin slices show the gradual increase in aggregate density from the cuticle to the surface of the crust (Fig. 2a, c, and e). In contrast, horizontal ultrathin sections obtained at each of the three identified mineral levels reveal different bacterial densities.

The lower level of the mineral crust (Fig. 2a and b) corresponds to the lower side of the mineral crust and is characterised by a heterogeneous distribution of mineral particles, a distribution that is very fine and seems to correspond to clusters of less than $500 \mathrm{~nm}$ size (Fig. 2a). Their morphology seems directly related to the bacterial shape. TEM images (Fig. 2b) reveal that the lower level is characterised by a high density of rod-shaped bacteria; mineral precipitation occurs on the cell walls of these bacteria (Fig. 3a). The mineral precipitates as individual globular concretions of 10 to 30 $\mathrm{nm}$ diameter, that tend to undergo agglomeration into larger concretions. High resolution images (Fig. $3 b$ and c) reveal that the minerals appear as diffuse precipitates on secretions of the bacteria, i.e. exopolysaccharides. TEM observations of vertical sections of all the analysed samples reveal that the bacteria form a dense community close to the cuticle, a location in which mineral particles are almost absent because of the probable presence of bacterial secretion (Fig. 4). Interestingly, the methanotrophic bacteria, characterised by their stacks of intracytoplasmic membranes (Fig. 3c), are frequently observed at the lower level of the crust. Most often they aggregate in isolated groups that remain free of any mineral precipitates (Fig. 3d). 

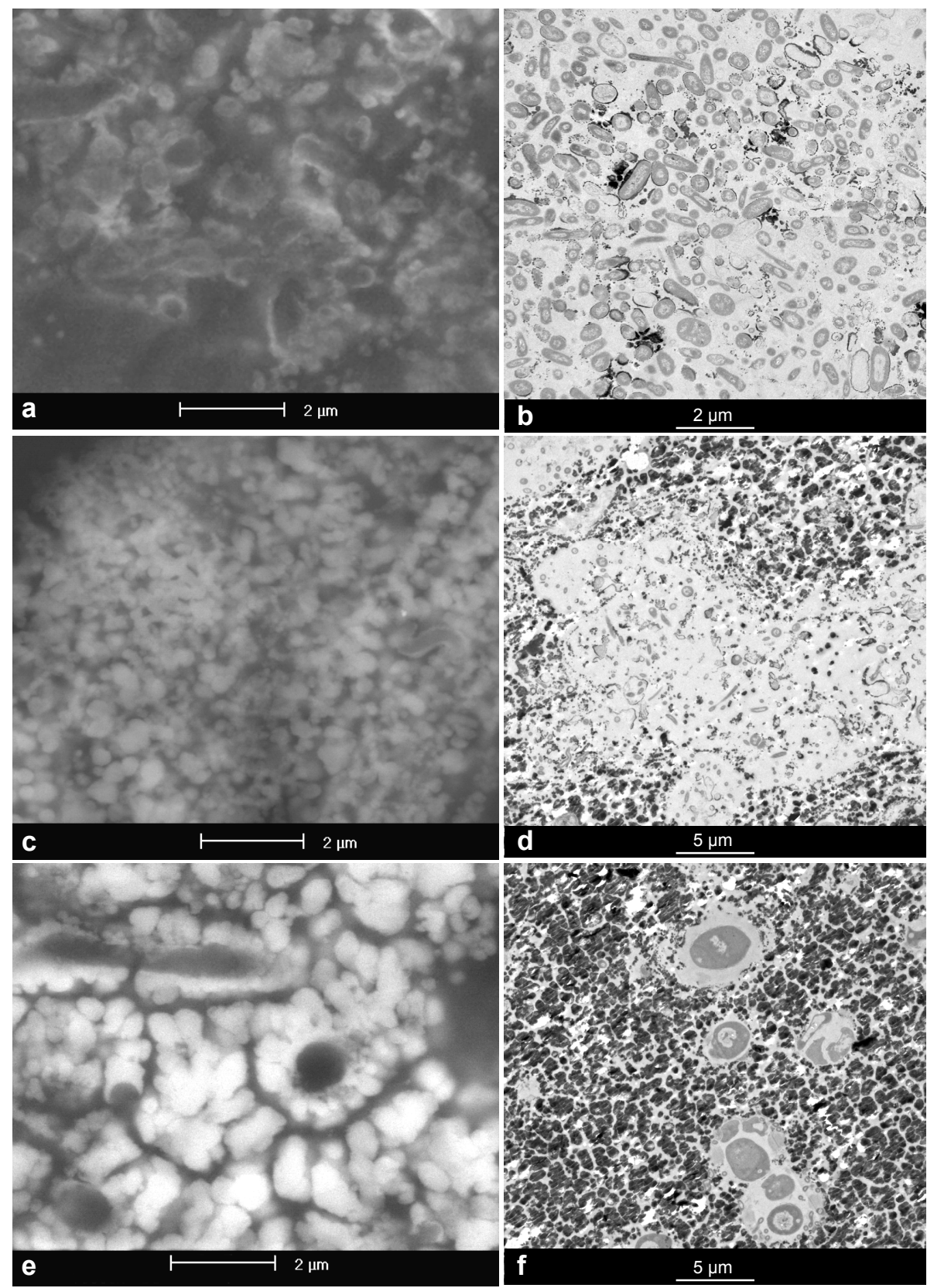

Fig. 2. The three levels of the mineral crust. Comparison between the electron back scattering images of the polished-thin sections (vertical sections) revealing the mineral densities and structures (left column) and the TEM micrographs of horizontal cross-sections exhibiting mineral associated with bacterial community (right column) at the lower level (a and b), the median level (c and d) and the upper level (e and $\mathbf{f}$ ).

The median level of the crust exhibits larger mineral concretions, globular in shape, (Fig. $2 \mathrm{c}$ and d). These globular concretions often meet to form larger ones that exhibit a botryoidal structure. In the horizontal cross-sections, the aggregate density appears rather heterogeneous and consists of highly mineralised patches interspersed with bacteria rich areas. The bacterial density in the median layer is always smaller than in the lower layer; there are fewer rod-shaped bacteria. Moreover, ghosts of bacteria are also observed
(Fig. 3e and f) in TEM images. These ghosts have bacterial shapes that are completely enclosed in a heavy mineral sheath. Sometimes the bacteria are still present but appear either to be damaged or as membrane remain (Fig. 3e and f). In other cases, the mineral sheath appears to be empty or to have been recolonised by other rod-shaped bacteria. These observations suggest that mineral formation may influence the survival rate of the bacteria. 


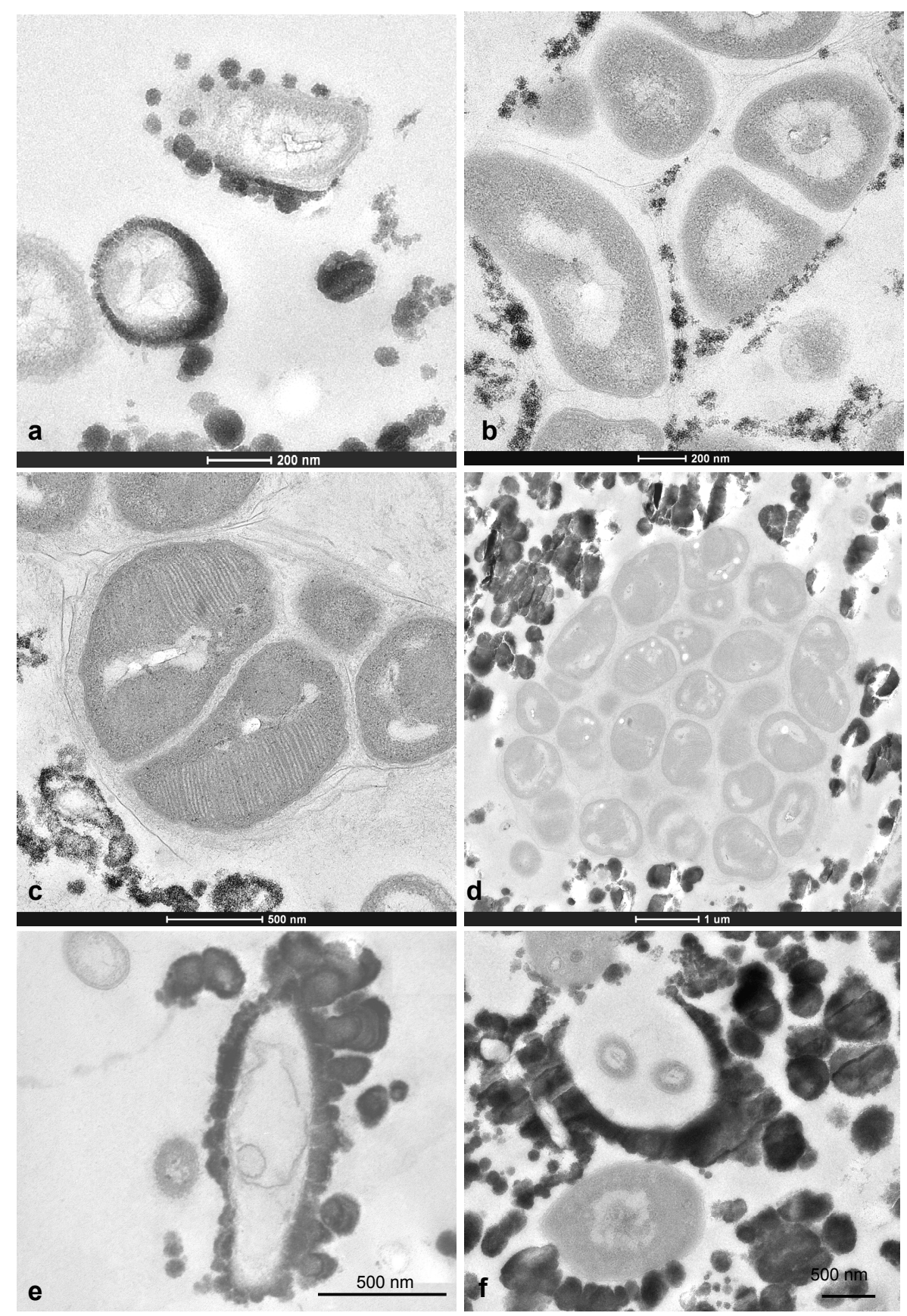

Fig. 3. TEM views illustrating the different ways the minerals may be deposited on the rod-shaped bacteria in Rimicaris exoculata. (a) Mineral deposition in direct contact with the bacteria cell walls. (b) Mineral deposition on secreted bacterial substance. (c) and (d) Methanotrophic bacteria surrounded by mineral deposits. (e) and (f) Bacterial ghosts coated with minerals and bacterial recolonization of the mineral sheaths.

The upper level of the mineral crust contains very large concretions with diameters of up to $2 \mu \mathrm{m}$ (Fig. 2e and f). The grape-like concretion shapes with deep indentations suggest that they result from the aggregation of several smaller ones. TEM images reveal that the bacteria become very rare in this upper level. As may be observed in the horizontal sections, almost the only bacteria present are a few large, thin, bacterial filaments that perforate throughout the mineral crust. Moreover, the minerals are not in direct contact with the filament cell walls but form large sheaths at some distance from the cell walls (Fig. 2e). Even though the three step-levels of the mineral crust have been arbitrarily defined, they are 


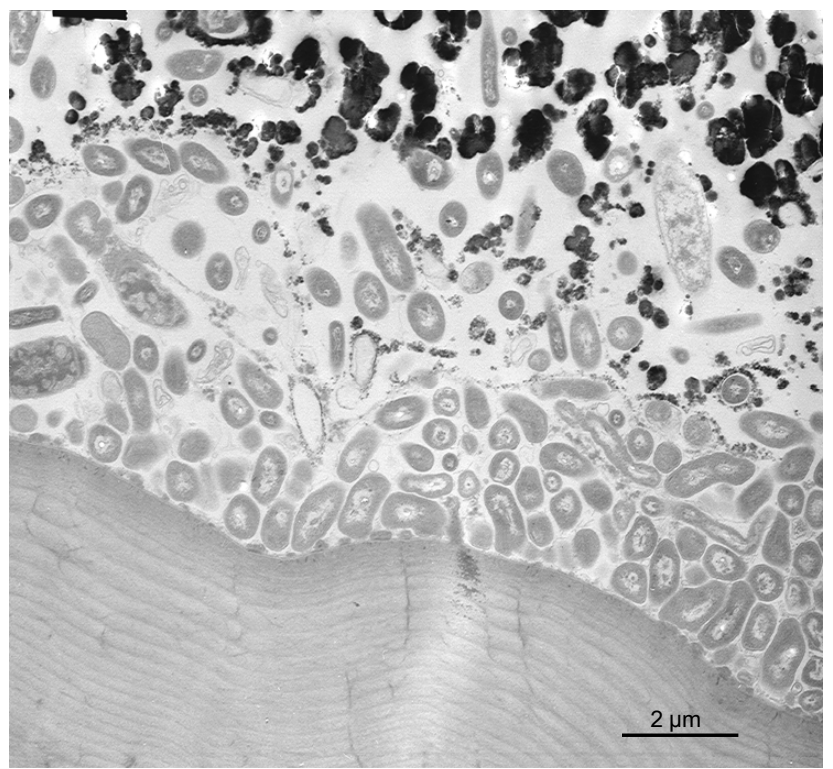

Fig. 4. Bacteria-mineral interactions in Rimicaris exoculata. TEM view of the lower level (vertical cross-section) where rod-shape bacteria are very abundant. Note that the bacteria seem to produce some substance which prevents any direct mineral deposition close to this layer.

representative of the different phases of the mineral formation and are characterised by an inverse correlation, from low to upper levels, between the amount of mineral deposits present and the bacterial density.

\subsection{Iron oxides identified by Mössbauer spectroscopy}

Mössbauer spectroscopy has been used to identify both the nature and oxidation states of the iron oxides found in the native minerals through the measurements of the iron-57 isomer shift and quadrupole splitting. The Mössbauer spectra, obtained at 85 and $295 \mathrm{~K}$ and between 4.2 and $60 \mathrm{~K}$ are shown in Figs. 5a and b, respectively. At 85 and $295 \mathrm{~K}$ the spectra consist of broadened quadrupole doublets, whereas below $60 \mathrm{~K}$ they consist of a superposition of broadened doublets and sextets. The observed temperature dependence of the Mössbauer spectra is typical of small superparamagnetic particles. The spectra have been fit with two symmetric quadruople doublets and one to three magnetic sextets; the average hyperfine parameters are given in Table 1 .

The weighted average isomer shift, $\langle\delta\rangle$, is typical of iron(III) (Shenoy et al., 1978) and spectral analysis indicates that at least $98 \%$ of the iron in the mineral crust must be present as iron(III); two percent by spectral area is the approximate detection limit for the presence of any iron(II). The average hyperfine parameters observed at 295 and $4.2 \mathrm{~K}$ are typical (Murad et al., 1987) of two-line ferrihydrite. Two-line ferrihydrite, $\mathrm{Fe}_{5} \mathrm{HO}_{8} \cdot 4 \mathrm{H}_{2} \mathrm{O}$, is a poorly crystalline mineral that forms spherical nanoparticles with a
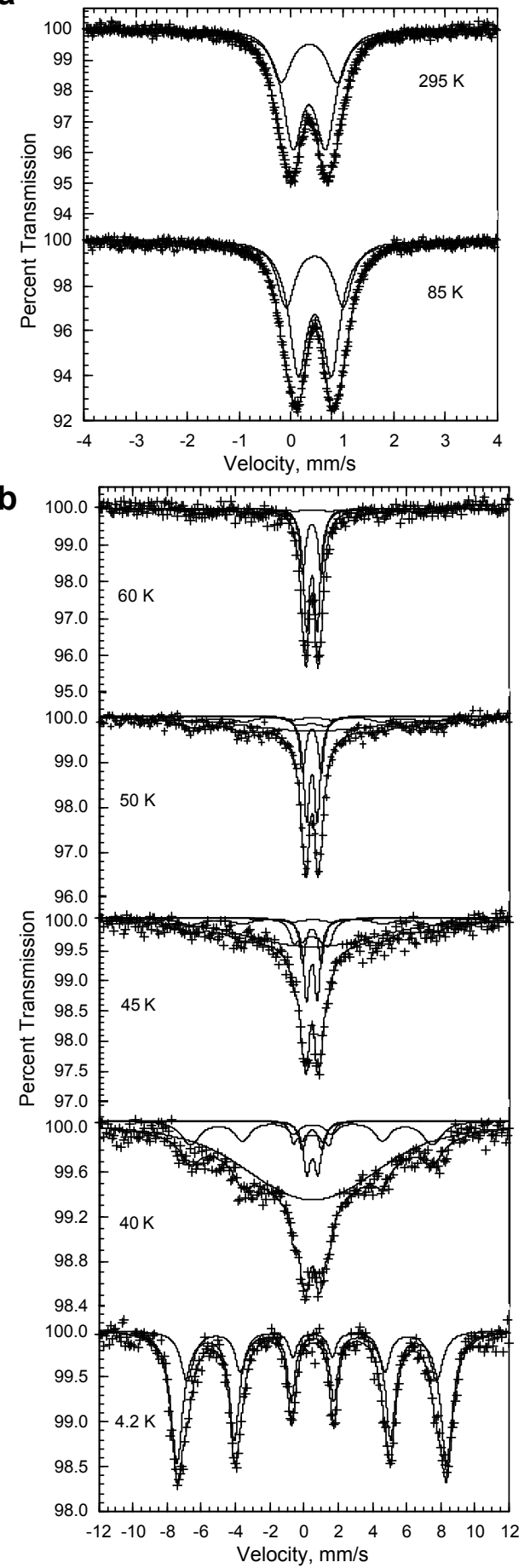

Fig. 5. (a) The 85 and $295 \mathrm{~K}$ iron- 57 Mössbauer spectra of minerals from the crust collected on the branchiostegites of three shrimps. (b) The iron-57 Mössbauer spectra of two superimposed branchiostegites parts of one shrimp obtained at the indicated temperatures. 
Table 1. Mössbauer spectral parameters obtained for the Rimicaris exoculata hydrothermal shrimp.

\begin{tabular}{|c|c|c|c|c|c|c|c|c|}
\hline Compound & $\begin{array}{l}T, \\
\mathrm{~K}\end{array}$ & $\begin{array}{l}<\delta> \\
\mathrm{mm} / \mathrm{s}^{*}\end{array}$ & $\begin{array}{r}<\Delta E_{Q}> \\
\mathrm{mm} / \mathrm{s}\end{array}$ & $\begin{array}{l}<H>, \\
\mathrm{T}\end{array}$ & $\begin{array}{l}<\Gamma> \\
\mathrm{mm} / \mathrm{s}\end{array}$ & $\begin{array}{l}\text { Area, } \\
\%\end{array}$ & $\begin{array}{l}\text { Abs. Area, } \\
(\% \varepsilon)(\mathrm{mm} / \mathrm{s})\end{array}$ & Assignment \\
\hline \multirow[t]{13}{*}{ Rainbow } & 295 & 0.358 & 0.78 & 0 & 0.46 & 100 & 7.302 & Superparamagnetic iron(III) \\
\hline & 225 & 0.403 & 0.78 & 0 & 0.38 & 100 & 10.106 & Superparamagnetic iron(III) \\
\hline & 155 & 0.439 & 0.79 & 0 & 0.39 & 100 & 11.010 & Superparamagnetic iron(III) \\
\hline & 85 & 0.465 & 0.80 & 0 & 0.42 & 100 & 11.064 & Superparamagnetic iron(III) \\
\hline & 60 & 0.464 & 0.80 & 0 & 0.42 & 82 & 6.196 & Superparamagnetic iron(III) \\
\hline & & 0.461 & -0.04 & 39.6 & 1.13 & 18 & 1.314 & Partially blocked iron(III) \\
\hline & 50 & 0.464 & 0.80 & 0 & 0.42 & 36 & 3.6935 & Superparamagnetic iron(III) \\
\hline & & 0.463 & -0.05 & 21.6 & 4.35 & 64 & 6.693 & Partially blocked iron(III) \\
\hline & 45 & 0.464 & 0.80 & 0 & 0.42 & 23 & 2.332 & Superparamagnetic iron(III) \\
\hline & & 0.463 & -0.06 & 28.1 & 3.54 & 77 & 7.753 & Partially blocked iron(III) \\
\hline & 40 & 0.464 & 0.80 & 0 & 0.42 & 8 & 0.901 & Superparamagnetic iron(III) \\
\hline & & 0.463 & -0.06 & 24.0 & 3.75 & 92 & 10.075 & Partially blocked iron(III) \\
\hline & 4.2 & 0.481 & -0.045 & 47.8 & 0.56 & 100 & 10.727 & Blocked iron(III) \\
\hline
\end{tabular}

* The isomer shifts are given relative to room temperature $\alpha$-iron powder.

Table 2. Typical elemental EDX microanalysis of the mineral crust of Rimicaris exoculata. Data are expressed as both weight and atomic percents.

\begin{tabular}{ccc}
\hline Element & Wt $\%$ & At $\%$ \\
\hline C K & 37.5 & 57.3 \\
O K & 25.5 & 29.2 \\
MgK & 0.4 & 0.3 \\
SiK & 1.7 & 1.1 \\
P K & 0.6 & 0.3 \\
S K & 0.3 & 0.2 \\
CIK & 0.3 & 0.2 \\
CaK & 0.6 & 0.3 \\
FeK & 32.7 & 10.8 \\
\hline
\end{tabular}

a diameter of between 2 and $7 \mathrm{~nm}$, a diameter that depends upon both the crystallinity of the material and the presence of impurities. Also for the same reasons, the average hyperfine field observed at $4.2 \mathrm{~K}$ may be reduced from 50 to 46.5 T. In the specimens understudy, the average hyperfine field of $47.8 \mathrm{~T}$ corresponds to a reasonably well crystallised sample. The blocking temperature, i.e. the temperature at which the absorption areas of the doublets and sextets are equal, is $55 \pm 2 \mathrm{~K}$. By using the anisotropy constant (Murad et al., 1987) of $4 \times 10^{4} \mathrm{~J} / \mathrm{m}^{3}$ for $5 \mathrm{~nm} \mathrm{Fe}_{5} \mathrm{HO}_{8} \cdot 4 \mathrm{H}_{2} \mathrm{O}$ particles, an average particle diameter of $5.6 \mathrm{~nm}$ is obtained.

\subsection{Quantitative EDX microanalyses}

BSE images of polished thin slices of frozen specimens provide a detailed map of the mineral particles in the crust. EDX microanalyses $(n=14)$ performed in ESEM give accurate qualitative and quantitative determinations of the ele-

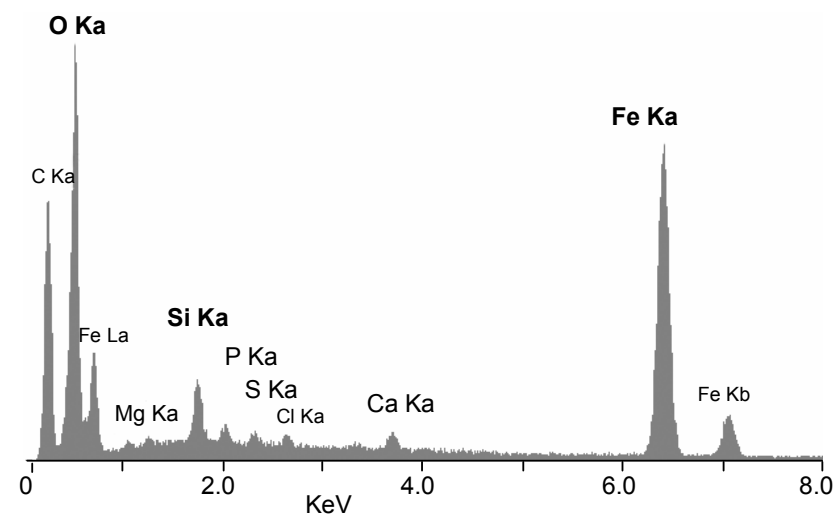

Fig. 6. Elemental EDX microanalyses of the mineral crust of Rimicaris exoculata. (a) A typical spectrum obtained on mineral particles of up to $2 \mu \mathrm{m}$ diameter. The peaks are labelled with the EDX line of the corresponding element.

mental composition of the mineral deposits. These microanalyses reveal the predominance of iron, with a $K_{\alpha}$ peak at $6.400 \mathrm{keV}$ and a $K_{\beta}$ peak at $7.059 \mathrm{keV}$, and oxygen with a $K_{\alpha}$ peak at $0.5425 \mathrm{keV}$, in the mineral crust (Fig. 6). Minor amounts of silicon with a $K_{\alpha}$ peak at $1.740 \mathrm{keV}$, calcium with a $K_{\alpha}$ peak at $3.690 \mathrm{keV}$ and a $K_{\beta}$ peak at $4.012 \mathrm{keV}$, phosphorus with a $K_{\alpha}$ peak at $2.013 \mathrm{keV}$, magnesium with a $K_{\alpha}$ peak at $1.253 \mathrm{keV}$, and sulphur with a $K_{\alpha}$ peak at $2.307 \mathrm{keV}$, have also been detected. Elemental quantitative analyses yield the weight and atomic percentages of the elements present, see Table 2 . In order to determine the relative amount of the iron oxides and other minerals in the concretions, we subtract the $\mathrm{C}$ of the $\mathrm{C}$-coating and the $\mathrm{C}, \mathrm{O}$ and $\mathrm{Cl}$ of the embedding resin. It was also assumed that the minor elements such as $\mathrm{Si}, \mathrm{Ca}, \mathrm{Mg}, \mathrm{S}$ and $\mathrm{P}$ are present as silicate 
Table 3. Mineralogical characterisation of the mineral crust in Rimicaris exoculata. Data are expressed in atomic percentages and results from EDX quantitative analyses $(n=14)$ of polished thin slices of minerals from two frozen specimens. Mean values have been calculated after removing the peripheral elements inherent to the resin and the carbon coating. The amount of available oxygen for each mineral or ligands is calculated by assuming the presence of $\mathrm{SO}_{4}^{2-}$ and $\mathrm{PO}_{4}^{3-}$ anionic groups as well as silicate with at least two $\mathrm{O}$ atoms associated to each $\mathrm{Si}$ atom. The percentages of mineral constituents and ligands have been calculated under the assumption of their most probable occurrence. All values are mean \pm standard deviation.

\begin{tabular}{lccccccc}
\hline Elements & $\mathrm{O}$ & $\mathrm{Fe}$ & $\mathrm{Si}$ & $\mathrm{S}$ & $\mathrm{P}$ & $\mathrm{Ca}$ & $\mathrm{Mg}$ \\
\hline Mean & $67.8 \pm 1.4$ & $27.3 \pm 0.7$ & $2.6 \pm 0.4$ & $0.5 \pm 0.1$ & $0.5 \pm 0.2$ & $0.7 \pm 0.1$ & $0.5 \pm 0.3$ \\
Available $\mathrm{O}$ & - & $58.5 \pm 3.1$ & $5.3 \pm 0.8$ & $2.1 \pm 0.4$ & $2.0 \pm 0.9$ & - & - \\
Minerals and & & $\mathrm{Fe}_{\mathrm{x}} \mathrm{O}_{\mathrm{y}}(\mathrm{OH})_{\mathrm{z}}+\mathrm{vH}_{2} \mathrm{O}$ & $\mathrm{Si}\left(\mathrm{O}_{2}\right)$ & $\mathrm{SO}_{4}^{2-}$ & $\mathrm{PO}_{4}^{3-}$ & $\mathrm{Ca}, \mathrm{MG}$ & $\mathrm{Total}$ \\
Inorganic ligands & & $85.8 \pm 2.9$ & $7.9 \pm 1.2$ & $2.6 \pm 0.5$ & $2.5 \pm 1.2$ & $1.2 \pm 0.49$ & $9.9 \pm 0.2$ \\
\hline
\end{tabular}

cations and anions (sulphate and phosphate) respectively as they appear as the most probable ligand forms, as suggested by Châtellier et al. (2001, 2004) and Fortin and Langley (2005). The associated oxygen was calculated according to the stoichiometric ratio in the forms of $\mathrm{SO}_{4}^{2-}$ and $\mathrm{PO}_{4}^{3-}$ and reported as available $\mathrm{O}$ in Table 3. For silicate, a minimum of two oxygen atoms arbitrary attributed to each $\mathrm{Si}$ atom that appears as $\mathrm{Si}\left(\mathrm{O}_{2}\right)$ in Table 3. The remaining $\mathrm{O}$ was considered as available for $\mathrm{Fe}$ and taken into account in the calculation of the $\mathrm{Fe} / \mathrm{O}$ ratio. The results of these calculations give the relative contribution of all the mineral constituents of the concretions (Table 3). They show that iron(III) oxides correspond to ca. $85 \mathrm{At} \%$ (ca. $90 \mathrm{Wt} \%$ ) of the minerals present in the crust, as confirmed by Mössbauer spectroscopy. This value does not include hydrogen atoms (not measurable) that may represent $25-50 \%$ of the atoms in the mineral, according to the general Ferrihydrite formula and hydration state but does never exceed $2 \mathrm{Wt} \%$. The contribution of the inorganic ligands in the concretions is approximately evaluated at $8 \%$ for $\mathrm{Si}\left(\mathrm{O}_{2}\right), 2.5 \%$ for $\mathrm{SO}_{4}^{2-}$ and $2.5 \%$ of $\mathrm{PO}_{4}^{3-}$ and $1.2 \%$ for $\mathrm{Ca}$ and $\mathrm{Mg}$. It is very probable that $\mathrm{Ca}^{2+}$ and $\mathrm{Mg}^{2+}$ are combined in salts with the anions $\mathrm{SO}_{4}^{2-}$ and $\mathrm{PO}_{4}^{3-}$ because of the perfect accordance with the stoichiometric ratio in $(\mathrm{Ca}$, $\mathrm{Mg}) \mathrm{SO}_{4}$ and $(\mathrm{Ca}, \mathrm{Mg})_{3}\left(\mathrm{PO}_{4}\right)_{2}$. $\mathrm{Ca}, \mathrm{Mg}$ salts could thus represent approximately $6 \%$ in the concretions.

Comparative elemental EDX microanalyses carried out on 12 polished thin slices of glutaraldehyde-fixed specimens reveal very similar proportions of the minor ligands suggesting that they are not solubilised or removed by the aqueous preparation procedure. However, these analyses differ from those of the frozen sample by the $\mathrm{Fe} / \mathrm{O}$ ratio in the iron oxide, i.e. after the subtraction of the oxygen linked to minor elements, see Table 4 . The Fe/O ratio is 0.47 in the frozen specimens while it reaches 0.60 in the glutaraldehyde-fixed specimens. These measured $\mathrm{Fe} / \mathrm{O}$ ratios are statistically different as is indicated by a paired $t$-test which yields $t=7.1$, $d . f .=11$, and $P=0.00002$. Hence, the atomic percentage of oxygen is lower in the glutaraldehyde-fixed specimens, in which the glutaraldehyde could act as a reducing agent and modify the iron oxidation state in the mineral particles.
Table 4. Comparison of the mineralogical composition between frozen and glutaraldehyde-fixed specimens. EDX elemental quantitative analysis of fourteen frozen samples and twelve glutaraldehyde-fixed samples. The data have been obtained with the same experimental procedure. All values are mean \pm standard deviation.

\begin{tabular}{lcccc}
\hline & \multicolumn{2}{c}{ Frozen sp. } & \multicolumn{2}{c}{ Glutharaldehyde-fixed sp. } \\
\hline Elements & $\mathrm{O}$ & $\mathrm{Fe}$ & $\mathrm{O}$ & $\mathrm{Fe}$ \\
Mean & $67.8 \pm 1.4$ & $27.3 \pm 0.7$ & $64.5 \pm 1.4$ & $28.3 \pm 1.3$ \\
Available O & - & $58.5 \pm 3.1$ & - & $47.8 \pm 3.0$ \\
Ratio Fe/O & \multicolumn{2}{c}{$0.47 \pm 0.03$} & \multicolumn{2}{c}{$0.60 \pm 0.05^{\mathrm{a}}$} \\
\hline
\end{tabular}

a Significantly different.

\subsection{Structure and composition of the crust minerals}

TEM images obtained on $\mathrm{U} / \mathrm{Pb}$ contrasted ultra-thin vertical sections indicate that most of the mineral concretions, which have diameters ranging from 200 to $600 \mathrm{~nm}$, exhibit layered features in the lower level of the crust (Fig. 7a and b). Most of the specimens exhibit a multilayered pattern with a periodicity of a few nanometers, a pattern that suggests that these concretions are composed of ca. 5 to 10 successive strata. All of these strata appear as concentric growth layers originating from a unique nucleation centre, as multiglobular particles that change their shape and, for the outer particles, follow the outer particle border (Fig. 7b). Neighbouring concretions also exhibit layered patterns that may correspond to similar mineral deposition sequences (Fig. 7a). Mineral nucleation and deposition occur either close to the rod-shaped bacteria walls or in their near-neighbour environment. Several nucleation centres are located close to the same bacteria and the accumulation of strata leads to the aggregation of mineral particles that, as a consequence, exhibit a grape-like shape (Fig. 7b). STEM-HAADF images of particles from frozen specimens give an inverted mass contrast of the strata. These images reveal the reality of the strata in terms of the changing aggregate density and/or the composition within the particles (Fig. 7c and d). 


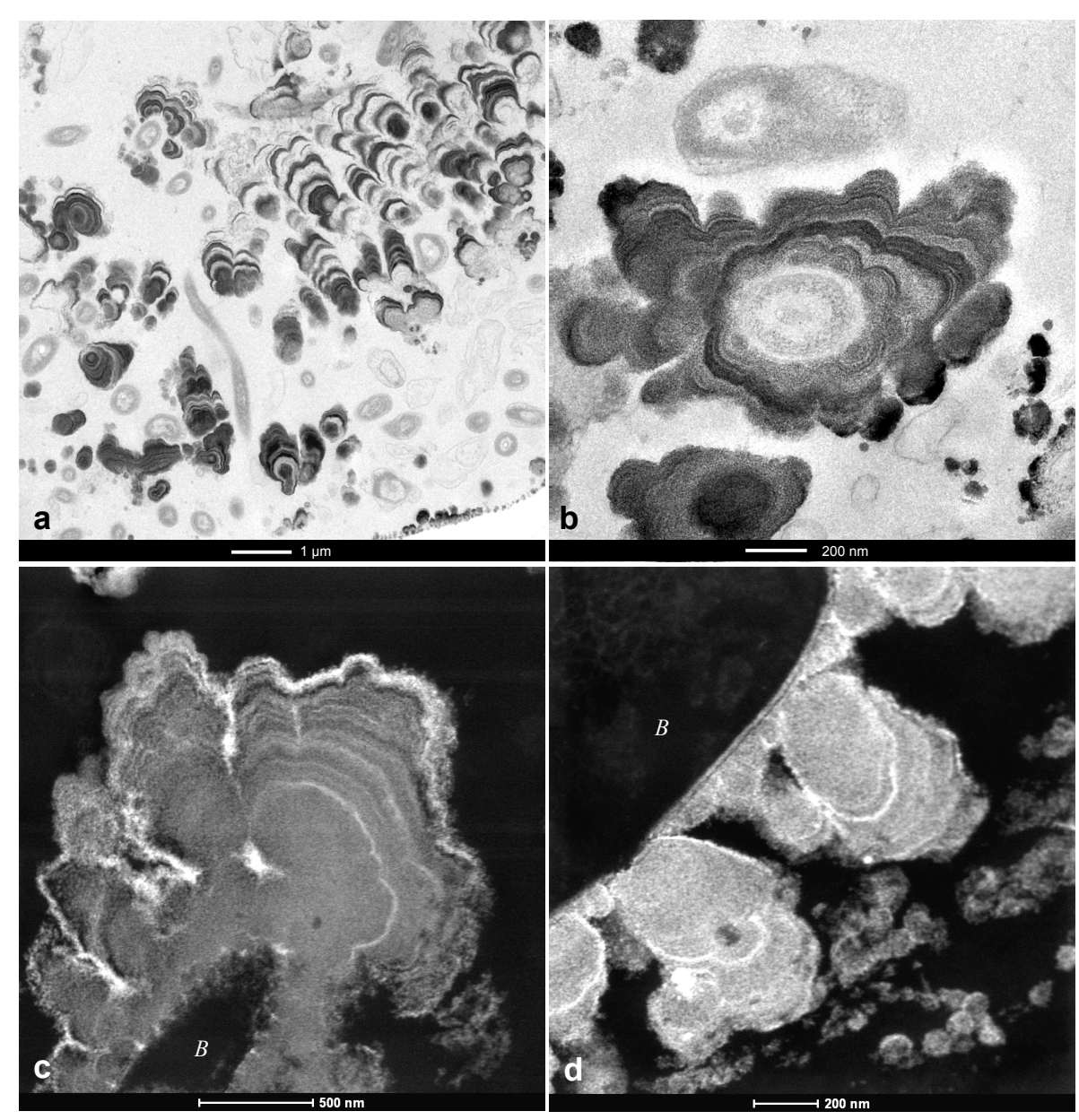

Fig. 7. (a) and (b) TEM views of the mineral particles in the lower level of the crust. The occurrence of contrasted strata is clearly visible. (c) and (d) STEM images of ultrathin sections of non-contrasted mineral particles revealing the different nature of the mineral strata. $B$ indicates the bacteria.

In order to determine the exact nature of these strata, EDX nanoanalyses have been carried out by STEM along a direction perpendicular to the strata of some particles observed in the ultrathin sections. The experimental procedure for obtaining these line profiles of 1 to $1.5 \mu \mathrm{m}$ length is based on the acquisition of a sequence of ca. 700 EDX spectra per line profile. Subsequent data analysis can differentiate different elements through the number of counts that correspond to a given element found along the line. Figure 8 illustrates a typical elemental profile for iron, oxygen, and silicon along a $1.2 \mu \mathrm{m}$ line through a stratified mineral particle. The clear lighter coloured strata in Fig. 8a correspond to a higher iron and oxygen content than is found in the dark strata, see Fig. 8b. In spite of a low number of counts, the silicon profile seems to correlate well with those of iron and oxygen. In order to more accurately characterise the nature of the mineral strata, quantitative elemental analyses have been performed at specific points, i.e. points 1, 2, and 3 in Fig. 8a, at well separated strata along the line profile. The results (Table 5) confirm that the iron and oxygen atomic percentages are high at the lighter strata, points 1 and 3 , and very low in the dark strata, position 2. The strata result thus rather from changes in the aggregation density than from real compositional differences.

\section{Discussion}

A multifacitated analysis carried out on the mineral crust of R. exoculata reveals a mineral content of $85 \%$ iron(III) oxide and associated with $15 \%$ of minor inorganic ligands, possibly present as silicate and $(\mathrm{Ca}, \mathrm{Mg})$ sulphate and phosphate. The Mössbauer spectral results indicate that the iron(III) oxide corresponds to two-line ferrihydrite, $\mathrm{Fe}_{5} \mathrm{HO}_{8} \cdot 4 \mathrm{H}_{2} \mathrm{O}$, which is present in nanometric particles of less than $5 \mathrm{~nm}$ diameter. A transmission and scanning electron microscopic study of the mineral crust reveals the concretions exhibit 
Table 5. Elemental quantitative analyses expressed in atomic percent along the line profile of the iron oxide particle shown in Fig. 8a. Positions (1), (2), and (3) correspond to the positions indicated in Fig. 8a.

\begin{tabular}{cccc}
\hline \% At & $\mathrm{Fe}(\mathrm{K})$ & $\mathrm{O}(\mathrm{K})$ & $\mathrm{Si}(\mathrm{K})$ \\
\hline$(1)$ & 4.62 & 10.95 & 0.55 \\
$(2)$ & 1.07 & 4.57 & 0.34 \\
$(3)$ & 1.99 & 6.54 & 0.36 \\
\hline
\end{tabular}

stratified layers suggesting a sequential deposition with alternating layers of differing elemental density and composition. The description of the bacteria-mineral interactions suggests that both biotic and abiotic process could influence the mineral formation in the R. exoculata ectosymbiosis.

\subsection{Iron oxides}

Mössbauer spectral results have confirmed that the mineralbacteria associated crust which coats the branchiostegite of Rimicaris exoculata is mainly composed of a hydrous iron(III) oxide identified as two-line ferrihydrite, $\mathrm{Fe}_{5} \mathrm{HO}_{8} \cdot 4 \mathrm{H}_{2} \mathrm{O}$ (Jambor and Dutrizac, 1998). These results are in agreement with the conclusions based on transmission electron microscopy-electron energy loss spectroscopy (TEM-EELS) of minerals of $R$. exoculata mouthparts (Gloter et al., 2004). Further, the particle diameter of 2 to $7 \mathrm{~nm} \mathrm{ob-}$ tained from the Mössbauer spectral results is in complete agreement with that obtained by high-resolution electron microscopic images or structural analyses (Gloter et al., 2004; Michel et al., 2007). However, although an earlier TEMEELS analysis (Gloter et al., 2004) indicated a mixture of 55 to $66 \%$ iron(III) and 45 to $34 \%$ iron(II), only iron(III) has been detected in the Mössbauer spectra. Hence, if it is assumed that limit of detection for iron(II) is $2 \%$, iron(III) represents more than $98 \%$ of the total iron present. This difference in the oxidation state of iron may result from the experimental procedure used herein and the glutaraldehyde-fixation used for the TEM-EELS analysis as is discussed below.

Mössbauer spectroscopy utilises bulk samples of the mineral crust and hence, the results are averaged over a rather large number of concretions, in contrast with the results obtained from electron microscopic techniques that are representative of small portions of the samples. Further, there is neither radiation damage nor preparative damage of the absorbers in the Mössbauer spectral experiments. In contrast, exposure to an electron beam can result in atomic displacement, electronic reduction, electron-beam sputtering and/or heating, electrostatic charging, and radiolysis (Egerton et al., 2004). In a recent study using EELS to evaluate the effects of electron beam damage to ferrihydrite, Pan et al. (2006) observed the reduction of iron(III) to iron(II). These results a

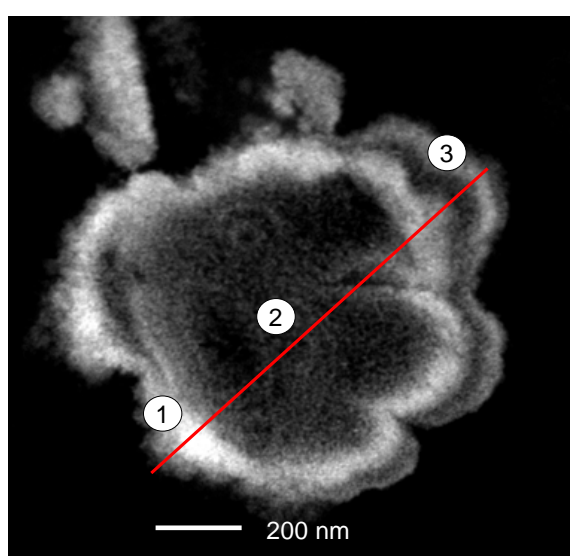

b

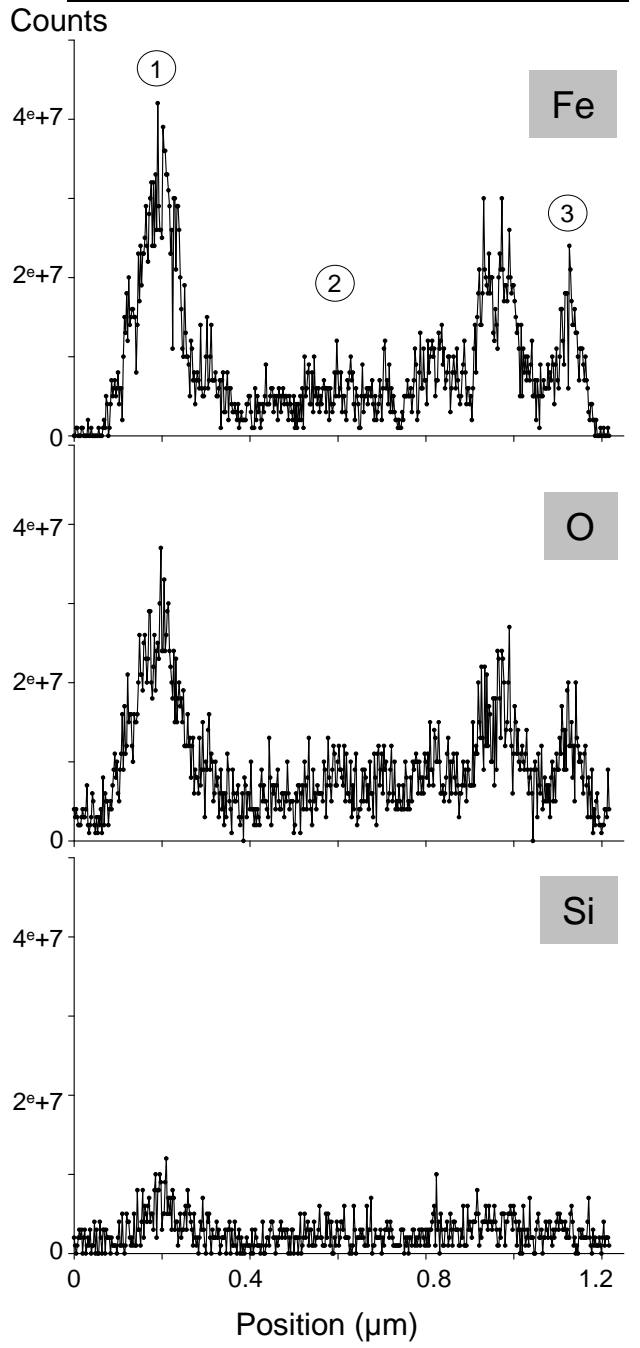

Fig. 8. (a) STEM pictures of the analysed particle exhibiting contrasted strata. The red line corresponds to the spectral profile line of $1.2 \mu \mathrm{m}$ length. The numbers 1 to 3 indicate the points where the elemental quantitative analysis given in Table 5 was carried out. (b) Element specific spectra acquired along the red profile line. Points 1 to 3 are also indicated at their corresponding positions on the iron spectrum. 
highlight how investigations carried out under high vacuum in a transmission electron microscope may cause substantial and perhaps unsuspected changes to a mineral sample.

Ferrihydrite is thus an essential mineral component of the mineral-bacteria associated crust in $R$. exoculata. The most common extracellular biogenic iron oxides include oxyhydroxides, e.g. goethite, lepidocrocite, akaganeite, and poorly ordered phases, e.g. two-line and six-line ferrihydrite (Cornell and Schwertmann, 2003; Fortin and Langley, 2005). Furthermore, it is commonly accepted that the product of microbial micro-aerobic iron(II) oxidation is often identified as a poorly crystalline ferrihydrite. The observation of two-line ferrihydrite thus supports the hypothesis of the presence of iron-oxidisers among the ectosymbiotic bacterial community of $R$. exoculata (Zbinden et al., 2004) and validates the first observations on bacterial cultures (Cambon-Bonavita, pers. com.). In hydrothermal environments, ferrihydrite has previously been identified because it is commonly intermixed with lithoautotrophic iron(II) oxidizing bacteria, that act as a causative agent in the formation of the ferrihydrite (Emerson and Moyer, 2002; Kennedy et al., 2003, 2004; Little et al., 2004). Very few vent animals have been discovered to live in close association with iron oxide deposits. To the best of our knowledge, only the scaly-foot gastropod found in the hydrothermal vents at the Indian Ridge has been shown to exhibit scale-shaped structures, mineralised with iron sulphides on its foot (Goffredi et al., 2003; Waren et al., 2003). These structures are associated with bacteria but an iron isotopic analysis indicates that sulphur and iron in the sclerites originate from hydrothermal fluids rather than from bacteria (Suzuki et al., 2006). Herein, the presence of ferrihydrite in close interaction with hydrothermal metazoan has been discovered for the first time, in the specific case of the vent shrimp R. exoculata.

Elemental quantitative analyses have been performed to determine the $\mathrm{Fe} / \mathrm{O}$ ratio. Because of the influence of the sample preparation for ultrastructural and elemental analyses, an alternative experimental procedure has been adopted in this study to reduce damage to the samples containing both bacteria and minerals. The samples for mineralogical analyses were frozen until used and were directly dehydrated by ethanol to avoid both air-contact and any aqueous chemical fixation. This procedure is based on the work of Mavrocordatos and Fortin (2002), who investigated the influence of sample preparation on poorly ordered biotic hydrous iron oxide. To assess the impact of sample fixation on the composition of the $R$. exoculata minerals, $\mathrm{Fe} / \mathrm{O}$ ratios determined through identical procedures have been compared between frozen and glutaraldehyde-fixed samples. The $\mathrm{Fe} / \mathrm{O}$ ratio of the glutaraldehyde-fixed minerals is significantly different from that of the frozen minerals. Thus sample preparation may modify the oxidation state of iron. The use of glutaraldehyde, a reducing agent, in addition to electron beam damage in TEM-EELS studies can explain the higher percentage of iron(II) reported by Gloter et al. (2004) in their mineral samples. The $\mathrm{Fe} / \mathrm{O}$ ratio in frozen minerals has been measured to be 0.47 , after subtraction of the oxygen associated with inorganic elements. This value cannot be compared with the Fe/O ratio of 0.33 obtained by Gloter et al. (2004) because both their analytical approach and mineralogical interpretations are quite different from those used herein. In contrast, the calculated $\mathrm{Fe} / \mathrm{O}$ ratio of 0.47 may be compared with the 0.417 ratio obtained for abiotic ferrihydrite (Mavrocordatos and Fortin, 2002 and references therein). Moreover, the calculated $\mathrm{Fe} / \mathrm{O}$ ratio of 0.47 in frozen minerals is similar to the $\mathrm{Fe} / \mathrm{O}$ ratio of 0.48 (Mavrocordatos and Fortin, 2002). In this study, quantitative TEM-EELS analyses have been performed on ferrihydrite sample experimentally obtained by the precipitation of hydrous ferric oxides in the presence of bacteria exhibiting extracellular polymers. Despites our slightly different methodologies, the similar $\mathrm{Fe} / \mathrm{O}$ ratio determined in the presence of bacteria, suggest the influence of the bacterial ectosymbiosis on the iron oxide formation.

In conclusion, for future research on $R$. exoculata minerals, sample preparation and, more specifically, the drying process and fixation of the biological samples must be accurately delineated because they both influence the surface properties of ferrihydrite and hence, the iron oxidation state and the $\mathrm{Fe} / \mathrm{O}$ ratio.

\subsection{Intrinsic inorganic constituents}

Even though ferrihydrite represents the main component of the mineral crust in $R$. exoculata, elemental and quantitative analyses of the mineral particles have revealed the presence of minor elements, such as $\mathrm{Si}, \mathrm{P}, \mathrm{Ca}, \mathrm{S}$, and $\mathrm{Mg}$. These elements are not considered as impurities (Gloter et al., 2004) but rather to form intrinsic inorganic constituents or ligands as suggested by Châtellier et al. (2004) because these authors found that their presence during the oxidation process can affect the mineralogy as well as the size and structure of the iron oxide particles. Because of their large surface areas, small particles of natural biogenic iron oxides generally contain adsorbed elements and ions, such as silicate, sulphate, phosphate, and manganese and aluminium cations (Fortin and Châtellier, 2003; Fortin and Langley, 2005). For example, nanoparticles of iron oxyhydroxide formed during the mineralisation process, can adsorb phosphate and silicate ions (Gilbert and Banfield, 2005). The adsorption of compounds on ferrihydrite from the surrounding aqueous milieu can affect its subsequent mineral ordering processes. Specifically, adsorption of silicates has been found to inhibit the conversion of ferrihydrite to more crystalline iron oxides, such as hematite and goethite (Kennedy et al., 2003; Châtellier et al., 2004). EDX nanoanalyses and elemental profiles performed on stratified $R$. exoculata mineral particles have revealed that silicon is already present in the early stages of mineral development. Thus, in $R$. exoculata, it is evident that inorganic ligands co-precipitate with iron oxide and are closely associated with it in the nanoparticles 
because the Si portion cannot be located separately from the iron oxide even on the nanometric scale reached in STEM. In the global characterisation of the mineral particles, we have assumed that they correspond to separated compounds such as silicate, $\mathrm{Ca}^{2+}, \mathrm{Mg}^{2+}, \mathrm{SO}_{4}^{2-}$, and $\mathrm{PO}_{4}^{3-}$, even though the authors consider that silicate, sulphate, phosphate, and magnesium and calcium cations are substituted or adsorbed to ferrihydrite. Their presence could also influence or stabilise this poorly crystalline form of iron oxide. Considering the stoichiometric ratio of $\mathrm{Ca}, \mathrm{Mg}$ and $\mathrm{P}$, it is probable that $\mathrm{SO}_{4}^{2-}$ and $\mathrm{PO}_{4}^{3-}$ are associated with $\mathrm{Ca}$ and $\mathrm{Mg}$ in $(\mathrm{Ca}, \mathrm{Mg})$ salts.

In order to further assess the distribution of the intrinsic inorganic constituents, EDX spectra acquired at line profiles have been performed on mineral particles exhibiting stratified features. At the atomic level, the results indicate that both iron and the other inorganic ligands are already associated within nanosized mineral particles. These observations reveal that iron, oxygen, and silicon proportions are constant but that the stratification is mainly the consequence of parallel variations of the concentration of all the constituting elements. Bacteria-associated mineral concretions appear to be identical and stratification seems to follow the same sequence within neighbouring mineral particles. These observations suggest that micro-environmental variations can occur in the nearby environment during the formation of the mineral particles. Uniform patterns of stratification on neighbouring particles can be explained by either environmental variations found at the shrimp growth level or by variations in the bacterial metabolism or activities. Similar patterns of stratification have been previously described on sediment microfacies and delineated as microstromatolite (Boulvain et al., 2001). The "microstromatolite" aspect of the mineral particles in $R$. exoculata provides is in favour of the biologically-mediated origin of iron oxides.

\subsection{Bacteria-mineral interactions}

In $R$. exoculata, iron oxide is complexed with intrinsic inorganic ligands in the presence of an important bacterial community. Both bacteria and the intrinsic inorganic ligands may play a role in mineral deposition. The term of biogenic iron oxides is commonly used to refer to iron oxide formed in the presence of bacteria. It also includes iron oxides formed as a direct result of microbial metabolism, i.e. through enzyme activities, or by passive mechanisms through which bacterial secretions trigger the formation and precipitation of iron oxides minerals (Fortin and Châtellier, 2003).

In $R$. exoculata, mineral deposition only occurs when the bacterial community is well-developed on the inner side of the branchiostegite (Corbari et al., 2008). This observation both contradicts the idea that iron oxide deposition could only result from a passive chemical-induced precipitation and supports the idea that bacteria must participate in mineral formation. Ferrihydrite formed in the absence of bacteria may be metastable and, typically after few days, trans- forms into a more structurally ordered iron oxide, such as hematite or goethite (Cornell and Schwertmann, 2003). Experiments performed on bacteriogenic ferrihydrite minerals obtained from the hydrothermal vents in the Axial Volcano (Pacific Ridge) demonstrated that even if they were subjected to heating of up to $80^{\circ} \mathrm{C}$, these minerals did not undergo a phase transition, and therefore suggested that the presence of bacteria inhibited the ferrihydrite transformation (Kennedy et al., 2004). Hence, inside the gill chamber of $R$. exoculata, ferrihydrite deposits appear to result from the presence of an abundant bacterial community and their formation is without any doubt biologically-mediated. If the moult cycle is used as a time-scale, the first ferrihydrite deposits are only observed when the bacterial density reaches a maximum in the early preecdysial individuals, i.e. the light-red or medium-red individuals, in stages $\mathrm{D}_{0}$ to $\mathrm{D}_{1}$ (Corbari et al., 2008). During the ten day moult cycle of the vent shrimp, the first mineral particles appear as ferrihydrite (Corbari and Compère, unpublished data) as early as the second post-moult day and continue to deposit until the tenth day, just before exuviation. Hence, we conclude that the bacterial community could contribute to the stabilisation of the iron oxide in the form of ferrihydrite. However, the bacteria organic moieties can hinder its transformation into a more crystallized iron oxide (Kennedy et al., 2004). In $R$. exoculata, such bacteria organic moieties can act together with the minor ligands and/or favour their incorporation in the concretions.

TEM observations of the bacterial morphotypes and their mineral interactions help to elucidate the biologicallymediated origin of the ferrihydrite deposits inside the gill chamber of $R$. exoculata. Different ways of mineral deposition have been identified, based on the recurrent observations of both bacterial morphotypes and mineral morphologies. Two association modes between minerals and rod shaped bacteria have been observed. In the first, iron oxide deposition occurs in close contact to the rod cell walls and, in the second, the iron oxide precipitates on polysaccharide or proteinaceous extracellular secretions at a significant distance from the bacterial cells. Such bacterial-mineral relationships have previously been described in $R$. exoculata, suggesting that rods are mainly involved in iron oxide formation (Anderson et al., 2008). The precipitation of iron oxides on or near the bacterial cell walls raises the question of the passive or active implication of the bacteria in their deposition.

Passive production of biogenic iron oxide is related to the reactivity of the bacterial cell walls. Mineral formation on the bacteria is generally not controlled by the organism but, rather results from the chemistry of the cell environment and the physicochemistry of the bacterial surface, (Fortin and Langley, 2005). This implies the adsorption and/or nucleation of iron oxide particles on bacterial cell walls that simply acts as a passive deposition template (Konhauser, 1997; Fortin and Châtellier, 2003; Klapper and Straub, 2005,). Whatever the type of surface structure the cell may have, the main charged chemical groups found at neutral $\mathrm{pH}$ are 
carboxyl, phosphoryl, and amino groups (Douglas and Beveridge, 1998). We thus suspect that similar mineral-bacteria associations take place in $R$. exoculata and that passive deposition of iron oxides could occur. However, the observation of bacterial ghost surrounded by dense mineral deposits suggest that the precipitation on iron (III) oxide in the vicinity of the cell or at the cell surface is harmful for the cells, probably by limiting substrate diffusion and uptake as assumed by Hallberg and Ferris (2004). Moreover, these bacteria encrusted in iron oxides are probably not ironoxidisers because iron oxides seem to improve their survival rates. Indeed, the most studied iron-oxidising bacteria, the neutrophilic aerobic iron(II) oxidisers from Gallionella and Leptothrix genus, are known to produce extracellular organic polymers that nucleate iron(III) precipitates at some distance of the bacterial envelope, avoiding encrustation that could cause cell death (Hallberg and Ferris, 2004; Kappler et al., 2005). Thus this active production of iron(III) oxide by metabolic oxidation of environmental iron(III) followed by bacterial-induced iron(III) oxide deposition on specific bacterial secretions must be distinguished from passive biologically-induced iron oxide precipitation. Hence, if ironoxidizing bacteria are present among the ectosymbiotic community in $R$. exoculata, they could use this strategy to keep their metabolism active and only those with extracellular secretion would be involved in iron oxide formation. The presence of a mineral boundary between the dense rod population, located at the lower layer and the mineralised area suggests a strategy involving the production of an extracellular organic material in order to prevent mineral deposition directly on the bacterial cell walls. This could also be true for the sheathed large filaments.

Interestingly, the appearance of methanotrophic bacteria clusters also support the above described mechanism in which bacteria exude organic substances to prevent any mineral deposition directly on their cell walls. Further, the presence of methanotrophic bacteria (Zbinden et al., 2008) suggests a more diversified bacterial community than previously mentioned (Segonzac et al., 1993; Zbinden et al., 2004; Corbari et al., 2008). Herein, methanotrophic bacteria show intact internal structures, i.e. stalks, and are distributed in clusters that indicate an active metabolism.

The three step-levels in the mineral crust formation previously described (Corbari et al., 2008) indicates that iron oxide particle growths are continuously initiated from the lower level, in close association with growing bacteria and subsequently grow into the median and upper levels. The mineralisation within the gill chamber could be described as a dynamic process in which particles increase in size and are simultaneously pushed upward by the formation of new particles. As has been illustrated herein, the lower level exhibits the highest bacterial density and is mainly composed of rod bacteria. This level may be considered as a bacterially active layer and its evolution in time, based on the moult cycle, shows continuous growth (Corbari et al., 2008). Neverthe- less, the concretions in their final state may results from biotic as well as from abiotic iron oxide precipitation, owing that, if present, iron-oxidising bacteria have to compete with abiotic oxidation of iron (Schmidt et al., 2008).

Finally, the weak mineral deposition, maximal rod-shaped bacterial density, and presence of extracellular secretions suggest that iron-oxidising bacteria may be located in this layer, a layer that may act as a potential reserve for active ectosymbiotic bacteria.

\section{Conclusions}

The multidisciplinary approach used in the present study provides new details about the iron oxide deposits associated with ectosymbiotic bacteria in Rimicaris exoculata. The mineral crust has been identified as a dense layer of two-line ferrihydrite nanoparticles associated with other intrinsic inorganic ligands. Ultrastructural observations and analytical data give evidences of the biologically induced deposition of iron oxides and support the role of bacterial morphotypes in active production of iron oxides. The process of mineralisation in the gill chambers of $R$. exoculata remains complex (co-occurrence of biotic and abiotic processes) because the combined effects of the intrinsic inorganic constituents and the bacterial influence are difficult to disentangle. But the evolution of the bacterial density in the three levels of the mineral crust is closely related to the amount of iron deposited and it is proposed that the lower level is the likely region where the iron-oxidising bacteria could be located. But the presence of a more diversified bacterial community raises the question on the metabolic or genetic diversity of these bacteria.

Because the main studies on $R$. exoculata ectosymbiosis have been performed on shrimps from the vent site Rainbow, the influence of the chemical vent environment should be studied in the future by comparing ectosymbiosis and its associated minerals in $R$. exoculata specimens collected at different vent sites, for instance TAG, Logatchev, and Snake Pit. This indirect approach could be used to evaluate how representative is the R. exoculata ectosymbiosis and, thus to determine whether iron oxidation represents the most favourable energetic-pathways for ectosymbiotic bacteria (Schmidt et al., 2008).

Acknowledgements. The authors thank A. Godfroy, the chief scientist of the EXOMAR cruise, as well as the captain and crew of the RV "Atalante" and the ROV "Victor" team. The authors also wish to express their appreciation to N. Decloux for her excellent technical assistance with transmission and scanning electron microscopy. This work was partly funded with the help of the MOMARNET program. The fellowship of L. Corbari and a part of this work were supported by the Belgian Fund for Joint Basic Research FNRS (F.R.F.C Belgium, conventions no. 2.4594.07.F). The authors also thank the centre of Microscopy of Liège (CAT $\mu$; dir. R. Cloots) for giving access to high performance equipment 
EM, funded by F.R.F.C and FEDER. F. Grandjean acknowledges, with thanks, the financial support of the FNRS, Belgium, through grants 9.456595 and 1.5.064.05.

Edited by: K. Küsel

\section{References}

Anderson, L., Halary, S., Lechaire, J.-P., Boudier, T., Frebourg, G., Marco, S., Zbinden, M., and Gaill, F.: Tomography of bacteria-mineral associations within the deep-sea hydrothermal vent shrimp Rimicaris exoculata, CR Chim., 11, 268-280, 2008.

Banfield, J. F., Welch, S. A., Zhang, H., Ebert, T. T., and Penn, L. P.: Aggregation-based crystal growth and microstructure development in natural iron oxyhydroxide biomineralization products, Science 289, 751-754, 2000.

Boulvain, F., De Ridder, C., Mamet, B., Préat, A., and Gillan, D.: Iron microbial communities in belgian frasnian carbonate mounds, Facies, 44, 47-60, 2001.

Casanova, B., Brunet, M., and Segonzac, M.: L'impact d'une épibiose bactérienne sur la morphologie fonctionnelle de crevettes associées à l'hydrothermalisme médio-atlantique, Cah. Biol. Mar., 34, 573-588, 1993.

Cavanaugh, C., McKiness, Z., Newton, I., and Stewart, F.: Marine chemosynthetic symbioses, in: The prokaryotes, edited by: Dworkin, M., Falkow, S., Rosenberg, E., Schleifer, K., and Stackebrandt, E., Springer, New York, 475-507, 2006.

Châtellier, X., Fortin, D., West, M., Leppard, G., and Ferris, F.: Effect of the presence of bacterial surfaces during the synthesis of fe-oxides by oxidation of ferrous ions, Eur. J. Miner., 13, 705714, 2001.

Châtellier, X., West, M. M., Rose, J., Fortin, D., Leppard, G. G., and Ferris, F. G.: Characterization of iron-oxides formed by oxidation of ferrous ions in the presence of various bacterial species and inorganic ligands, Geomicrobiol. J., 21, 99-112, 2004.

Corbari, L., Zbinden, M., Cambon-Bonavita, M.-A., Gaill, F., and Compère, P.: Bacterial symbionts and mineral deposits in the branchial chamber of the hydrothermal vent shrimp Rimicaris exoculata: Relationship to moult cycle, Aquatic Biology, 1, 225238, 2008.

Cornell, R. and Schwertmann, U.: The iron oxides - structure, properties, occurrences and uses 2nde edition, Weinheim ed., WileyVCH Verlag, 664 pp., 2003.

Desbruyeres, D., Biscoito, M., Caprais, J.-C., Colaco, A., Comtet, T., Crassous, P., Fouquet, Y., Khripounoff, A., Le Bris, N., and Olu, K.: Variations in deep-sea hydrothermal vent communities on the Mid-Atlantic Ridge near the Azores plateau, Deep-sea Res. PtI, 48, 1325-1346, 2001.

Douglas, S. and Beveridge, T. J.: Mineral formation by bacteria in natural microbial communities, FEMS Microbiol. Ecol., 26, 79_ 88, 1998.

Drach, P. and Tchernigovtzeff, C.: Sur la méthode de détermination des stades d'intermue et son application générale aux crustacés, Vie et Milieu, 18, 595-609, 1967.

Edwards, K. J., Bach, W., McCollom, T. M., and Rogers, D. R.: Neutrophilic iron-oxidizing bacteria in the ocean: Their habitats, diversity, and roles in mineral deposition, rock alteration, and biomass production in the deep-sea, Geomicrobiol. J., 21, 393404, 2004.
Egerton, R. F., Li, P., and Malac, M.: Radiation damage in the TEM and SEM, Micron, 35, 399-409, 2004.

Emerson, D. and Moyer, C. L.: Neutrophilic Fe-oxidizing bacteria are abundant at the Loihi seamount hydrothermal vents and play a major role in Fe oxide deposition, Appl. Environ. Microbiol., 68, 3085-3093, 2002.

Fortin, D., Ferris, G., and Scott, S.: Formation of Fe-silicates and Fe-oxides on bacterial surfaces in samples collected near hydrothermal vents on the southern explorer ridge in the northeast Pacific ocean, American Mineralogist, 83, 1399-1408, 1998.

Fortin, D. and Châtellier, X.: Biogenic iron-oxides, Recent Research Developments in Mineralogy, 3, 47-63, 2003.

Fortin, D. and Langley, S.: Formation and occurrence of biogenic iron-rich minerals, Earth-Sci. Rev., 72, 1-19, 2005.

Gebruk, A., Pimenov, N., and Savvichev, A.: Feeding specialization of bresiliid shrimps in the tag site hydrothermal community, Mar. Ecol.-Prog. Ser., 98, 247-253, 1993.

Gebruk, A. V., Southward, E. C., Kennedy, H., and Southward, A. J.: Food sources, behaviour, and distribution of hydrothermal vent shrimps at the mid-atlantic ridge, J. Mar. Biol. Ass. U.K, 80, 485-499, 2000.

Gilbert, B. and Banfield, J. F.: Molecular-scale processes involving nanoparticulate minerals in biogeochemical systems, Rev. Mineral. Geochem., 59, 109-155, 2005.

Gloter, A., Zbinden, M., Guyot, F., Gaill, F., and Colliex, C.: TEMEELS study of natural ferrihydrite from geological-biological interactions in hydrothermal systems, Earth Planet. Sci. Lett., 222, 947-957, 2004.

Goffredi, S., Hurtado, L., Hallam, S., and Vrijenhoek, R.: Evolutionary relationships of deep-sea vent and cold seep clams (mollusca: Vesicomyidae) of the "Pacifica" Species complex, Mar. Biol., 142, 311-320, 2003.

Hallberg, R. and Ferris, F. G.: Biomineralization by Gallionella, Geomicrobiol. J., 21, 325-330, 2004.

Jambor, J. L. and Dutrizac, J. E.: Occurrence and constitution of natural and synthetic ferrihydrite, a widespread iron oxyhydroxide, Chem. Rev., 98, 2549-2586, 1998.

Kappler, A., Schink, B., and Newman, D. K.: Fe(III) mineral formation and cell encrustation by the nitrate-dependent $\mathrm{Fe}(\mathrm{II})-$ oxidizer strain bofen1, Geobiology, 3, 235-245, 2005.

Kappler, A. and Straub, K. L.: Geomicrobiological cycling of iron, Rev. Mineral. Geochem., 59, 85-108, 2005.

Kennedy, C. B., Martinez, R. E., Scott, S., and Ferris, F. G.: Surface chemistry and reactivity of bacteriogenic iron oxidesfrom axial volcano, juan de fuca ridge, north-east pacific ocean, Geobiology, 1, 59-69, 2003.

Kennedy, C. B., Scott, S. D., and Ferris, F. G.: Hydrothermal phase stabilization of 2-line ferrihydrite by bacteria, Chem. Geol., 212, 269-277, 2004.

Konhauser, K. O.: Bacterial iron biomineralisation in nature, FEMS Microbiol. Rev., 20, 315-326, 1997.

Little, C., Glynn, S., and Mills, R. A.: Four-hundred-and-ninetymillion-year record of bacteriogenic iron oxide precipitation at sea-floor hydrothermal vents, Geomicrobiol. J., 21, 415-429, 2004.

Mavrocordatos, D. and Fortin, D.: Quantitative characterization of iron oxides formed on bacterial walls by tem-eels, Am. Miner., 87, 940-946, 2002. 
Michel, F. M., Ehm, L., Antao, S. M., Lee, P. L., Chupas, P. J., Liu, G., Strongin, D. R., Schoonen, M. A. A., Phillips, B. L., and Parise, J. B.: The structure of ferrihydrite, a nanocrystalline material, Science, 316, 1726-1729, 2007.

Murad, E. and Johnston, J. H.: Mössbauer spectroscopy applied to inorganic chemistry, G. J. Long, Ed, Plenum Press New York, 507 pp., 1987.

Murad, E. and Schwertmann, U.: Iron oxide mineralogy of some deep-sea ferromanganese crusts, Am. Miner., 73, 1395-1400, 1988.

Page, H. M., Fisher, C. R. and Childress, J.: The role of suspensionfeeding in the nutritional biology of a deep-sea mussel with methanotrophic symbionts, Mar. Biol., 104, 251-257, 1990.

Pan, Y., Brown, A., Brydson, R., Warley, A., Li, A., and Powell, J.: Electron beam damage studies of synthetic 6-line ferrihydrite and ferritin molecule cores within a human liver biopsy, Micron, 37, 403-411, 2006.

Polz, M. F. and Cavanaugh, C. M.: Dominance of one bacterial phylotype at a Mid-Atlantic Ridge hydrothermal vent site, PNAS, 92, 7232-7236, 1995.

Polz, M. F., Robinson, J. J., Cavanaugh, C. M. and Van Dover, C. L.: Trophic ecology of massive shrimp aggregations at a mid-atlantic ridge hydrothermal vent site, Limnol. Oceanogr., 43, 1631-1638, 1998.

Pond, D., Bell, M., Dixon, D., and Sargent, J.: Occurrence of 16:2(n-4) and 18:2(n-4) fatty acids in the lipids of the hydrothermal vent shrimp Rimicaris exoculata: Nutritional and trophic implications, Mar. Ecol.-Prog. Ser., 156, 167-174, 1997.

Rieley, G., Dover, C. L. V., Hedrick, D. B., and Eglinton, G.: Trophic ecology of Rimicaris exoculata: A combined lipid abundance/stable isotope approach, Mar. Biol., 133, 495-499, 1999.

Schmidt, C., Vuillemin, R., Le Gall, C., Gaill, F., and Le Bris, N.: Geochemical energy sources for microbial primary production in the environment of hydrothermal vent shrimps, Mar. Chem., 108, 18-31, 2008.

Segonzac, M., de Saint-Laurent, M., and Casanova, B.: L'énigme du comportement trophique des crevettes Alvinocarididae des sites hydrothermaux de la dorsale Médio-Atlantique, Cah. Biol. Mar., 34, 535-571, 1993.
Shenoy, G. K., Wagner, F. E., and Kalvius, G. M.: Mössbauer isomer shifts, edited by: Shenoy, G. K. and Wagner, F. E., NorthHolland Amsterdam, 49 pp., 1978.

Suzuki, Y., Kopp, R. E., Kogure, T., Suga, A., Takai, K., Tsuchida, S., Ozaki, N., Endo, K., Hashimoto, J., Kato, Y., Mizota, C., Hirata, T., Chiba, H., Nealson, K. H., Horikoshi, K., and Kirschvink, J. L.: Sclerite formation in the hydrothermal-vent "Scaly-foot" Gastropod-possible control of iron sulfide biomineralization by the animal, Earth Planet. Sci. Lett., 242, 39-50, 2006.

Van Dover, C., Fry, B., Grassle, F., Humphris, S., and Rona, P. A.: Feeding biology of the shrimp Rimicaris exoculata at hydrothermal vents on the mid-atlantic ridge, Mar. Biol., 98, 209-216, 1988.

Warén, A. S., Bengtson, S. K., Goffredi, S., and Van Dover, C. L.: A hydrothermal-vent gastropod with iron sulfide biomineralized dermal sclerites, Science, 302, 1007, 2003.

Williams, A. and Rona, P. A.: Two new caridean shrimps (bresiliidae) from a hydrothermal field on the mid-Atlantic Ridge., J. Crustac. Biol., 6, 446-462, 1986.

Wirsen, C. O., Jannasch, H. W., and Molyneaux, S.: Chemosynthetic microbial activity at Mid-Atlantic Ridge hydrothermal vent sites, J. Geophys. Res., 98, 9693-9703, 1993.

Zbinden, M. and Cambon-Bonavita, M.-A.: Occurrence of deferribacterales and entomoplasmatales in the deep-sea alvinocarid shrimp Rimicaris exoculata gut, FEMS Microbiol. Ecol., 46, 2330, 2003.

Zbinden, M., Le Bris, N., Gaill, F., and Compère, P.: Distribution of bacteria and associated minerals in the gill chamber of the vent shrimp Rimicaris exoculata and related biogeochemical processes, Mar. Ecol.-Prog. Ser., 284, 237-251, 2004.

Zbinden, M., Shillito, B., Le Bris, N., de Villardi de Montlaur, C., Roussel, E., Guyot, F., Gaill, F., and Cambon-Bonavita, M.-A.: New insigths on the metabolic diversity among the epibiotic microbial communitiy of the hydrothermal shrimp rimicaris exoculata, J. Exp. Mar. Biol. Ecol., 359, 131-140, 2008. 